\title{
Isolation of an epitheliotropic herpesvirus from white sturgeon Acipenser transmontanus
}

\author{
R. P. Hedrick ${ }^{1, *}$, T. S. McDowell ${ }^{1}$, J. M. Grofif ${ }^{1}$, S. Yun ${ }^{1}$, W. H. Wingfield ${ }^{2}$ \\ ${ }^{1}$ Department of Medicine, University of California, Davis, California 95616, USA \\ ${ }^{2}$ California Department of Fish and Game, Fish Disease Laboratory, Rancho Cordova, California 95670, USA
}

\begin{abstract}
Mortality among juvenile white sturgeon Acipenser transmontanus was associated with infections of the integument and oropharyngeal mucosa with a previously unrecognized herpesvirus. There was acanthosis and necrosis of the affected epithelium. No other tissues were found to be infected with the white sturgeon herpesvirus (WSHV). The virus was isolated from infected fish using a recently established cell line from the skin of white sturgeon (WSSK-1). There was no evidence for virus replication in 2 other lines from the white sturgeon heart (WSH-1) and spleen (WSS-2) nor in the CHSE214 and EPC lines derived from chinook salmon Oncorhynchus tshawytscha and common carp Cyprinus carpio, respectively. Cytopathic effects in WSSK-1 cells were characterized by syncytia 2 to $4 \mathrm{~d}$ after inoculation of cells at $15^{\circ} \mathrm{C}$. The virus grew in WSSK-1 cells at 10,15 and $20^{\circ} \mathrm{C}$ but not at 5 or $25^{\circ} \mathrm{C}$. Virions detected in both infected tissues and WSSK-1 cells were characteristic of herpesviruses: hexagonal capsids (mean diameter of $110 \mathrm{~nm}$ ) had a deeply staining core surrounded by the tegument and an external envelope with a diameter of $230 \mathrm{~nm}$. Experimentally induced infections and mortality of juvenile white sturgeon followed bath exposure to the virus grown in WSSK-1 cells. The association of WSHV with mortality among farm-reared and experimentally infected fish indicated that the virus can be one cause of mortality often observed in the early rearing phases of juvenile white sturgeon.
\end{abstract}

\section{INTRODUCTION}

Herpesviruses are the most represented group of DNA viruses found in fishes (Hedrick \& Sano 1989). At least 16 apparently distinct viruses belonging to the herpesviridae have been either isolated or observed in fish (Hedrick \& Sano 1989). Although a few of these viruses have been associated with serious clinical diseases and mortality (Wolf 1988), most have been found associated with hyperplastic growths or neoplasms of the integument (Hedrick \& Sano 1989). Although well represented among species of teleost fishes, herpesviruses have not been reported from the sturgeons.

White sturgeon Acipenser transmontanus have become an important commercial species in the state of California, USA, and numerous farms rear this fish for food, ornamental fish markets or for export as live fry. Two viruses have been detected in juvenile white sturgeon reared in California. The white sturgeon adenovirus (WSAV) was found associated with infections of the mucosa of the alimentary tract among

\footnotetext{
- Author for correspondence
}

juveniles reared from 1984 to 1986 (Hedrick et al. 1985) but has not been observed since. WSAV was believed to contribute to mortality in the early rearing phases and was shown to be experimentally transmitted from diseased sturgeon to previously healthy sturgeon.

A second virus, the white sturgeon iridovirus (WSIV), has been detected in several farm-reared or cultured populations of white sturgeon in California (Hedrick et al. 1990) and at least one site in Oregon (unpubl.). The virus infects epithelial cells of the integument and gills. These cells become hypertrophied and often deeply stained with hematoxylin. Virions with a mean diameter of $262 \mathrm{~nm}$ can be found within infected cells. In heavy infections, numerous infected cells are observed in the skin and gills of dead and moribund fish. The virus has now been isolated and partially characterized, including experiments which demonstrate its extreme virulence for juvenile white sturgeon (unpubl.). The apparently rapid spread of WSIV and the mortality associated with infections among populations of fish at several sturgeon farms is currently a major obstacle to commercial production.

The purpose of the following report is to characterize 
a third virus isolated from white sturgeon from a farmreared population with an increased mortality. In contrast to most reports of epitheliotropic herpesviruses. the virus was associated with mortality presumed to result from severe infections of the integument.

\section{MATERIALS AND METHODS}

Fish. Juvenile white sturgeon were brought to the laboratory from a commercial farm in northern California, USA. The fish ranged in weight from 1 to $3 \mathrm{~g}$ and were from a population with an increased mortality. The fish were subjected to standard necroscopy procedures which included examinations for both external and internal pathogens (Amos 1985). A second group of 20 fish from the same farm was obtained 3 wk later and again examined for presence of the virus. At this time a group of 1500 fish were transferred from the farm to the UC Davis Fish Pathology wet laboratory where they were placed into two 130 l aquaria for further observation. Freshly dead fish among the laboratory population were examined for the virus at least once weekly.

White sturgeon $(12.8 \mathrm{~g})$ used as recipients in experimental infections were obtained directly from a farm with no evidence of herpesvirus infections. The fish were held in $130 \mathrm{I}$ aquaria receiving $15^{\circ} \mathrm{C}$ well water. All groups of fish were fed a commercial moist trout diet.

Light microscopy. Moribund juvenile white sturgeon collected from the farm were examined for microscopic signs of infection in stained tissue sections. An incision of the abdomen was made to expose the viscera prior to placement of the fish into Davidson's fixative (Humason 1979). After $16 \mathrm{~h}$ fixation, samples were transferred to $70 \%$ ethanol and processed for standard paraffin embedding and sectioning. Tissue sections ( $5 \mu \mathrm{m})$ were stained with hematoxylin and eosin.

Cells and virus isolation. Five cell lines were used to isolate the virus. These included 3 lines developed in our laboratory from white sturgeon heart (WSH-1), spleen (WSS-2) and skin (WSSK-1) tissues (Hedrick et al. 1991, unpubl.). Two additional lines, chinook salmon embryo (CHSE-214) and Epithelioma papillosum cyprini (EPC), were also used (Fijan et al. 1983, Lannan et al. 1984). All 5 lines were grown in minimal essential medium (MEM) with Earle's salts supplemented with $10 \%$ fetal bovine serum (MEM-10), $50 \mathrm{IU} \mathrm{ml}^{-1}$ penicillin, $50 \mu \mathrm{g} \mathrm{ml}^{-1}$ streptomycin and $2 \mathrm{mM}$ L-glutamine at $20^{\circ} \mathrm{C}$.

The ventral integument or whole fish were homogenized and prepared for inoculation of cell lines as described by Amos (1985). After inoculation, all cells were incubated at $15^{\circ} \mathrm{C}$. When cytopathic effects were observed, a $0.1 \mathrm{ml}$ aliquot of culture fluid, with cells scraped from the monolayer, was inoculated to a second $25 \mathrm{~cm}^{2}$ flask with a $50 \%$ monolayer of WSSK-1 cells. Virus suspensions obtained after 2 subcultures were stored at $-70^{\circ} \mathrm{C}$. Virus recovery from fish in experimentally induced infections was attempted from homogenates made from a portion of the oropharyngeal mucosa and one operculum.

Electron microscopy. The WSSK-1 cells in a $25 \mathrm{~cm}^{2}$ flask were inoculated with $10^{3.5}$ TCID $_{50}$ of WSHV and then incubated at $15^{\circ} \mathrm{C}$. After $3 \mathrm{~d}$, the cells were fixed in $2.5 \%$ glutaraldehyde in $0.06 \mathrm{M}$ cacodylate buffer $\left(\mathrm{pH} \mathrm{7.4)}\right.$ for $4 \mathrm{~h}$ at $4^{\circ} \mathrm{C}$. The tissues were rinsed twice in buffer and then post-fixed in $1 \%$ aqueous $\mathrm{OsO}_{4}$, dehydrated through a graded ethanol series, infiltrated and embedded in epoxy resin. Thin sections (10 to $20 \mathrm{~nm}$ ) were stained with $4 \%$ uranyl acetate and lead citrate prior to examination with a Phillips EM 400 electron microscope at $80 \mathrm{kV}$. Samples from the oropharyngeal mucosa near the buccal opening of 3 infected fish from the farm population were also processed in the same manner but initial fixation was extended to $24 \mathrm{~h}$ at $4{ }^{\circ} \mathrm{C}$.

Growth temperatures. Growth of white sturgeon herpesvirus (WSHV) was examined at 5, 10, 15, 20 and $25^{\circ} \mathrm{C}$ in WSSK-1 cells. Six replicate $25 \mathrm{~cm}^{2}$ flasks of WSSK-1 cells were grown to ca $70 \%$ monolayers at $20^{\circ} \mathrm{C}$. Five flasks were inoculated with $100 \mathrm{TCID}_{50}$ of WSHV. After adsorption of the virus for $30 \mathrm{~min}$ at $20^{\circ} \mathrm{C}$, $5 \mathrm{ml}$ of MEM-2 was added to each flask. One flask was then placed at each of the selected temperatures and the uninoculated control flask was placed at $15^{\circ} \mathrm{C}$. At selected intervals between 1 and $43 \mathrm{~d}$ after inoculation, a $0.1 \mathrm{ml}$ aliquot was removed from each flask for titration of virus by $\mathrm{TCID}_{50}$ analysis on WSSK-1 cells incubated at $15^{\circ} \mathrm{C}$ for $14 \mathrm{~d}$. Concentration of the virus found at each temperature was then determined as described by Reed \& Muench (1938) and expressed as $\mathrm{TCID}_{50} \mathrm{ml}^{-1}$

Infection trial. The susceptibility of juvenile white sturgeon to WSHV was examined following their experimental exposure to a suspension of virus grown in WSSK-1 cells. Four groups of 20 fish (mean wt 12.8 g) were placed into replicate $130 \mathrm{l}$ aquaria containing 101 of $15^{\circ} \mathrm{C}$ well water Virus was added to 2 replicate aquaria to a final concentration of $10^{53} \mathrm{TClD}_{50} \mathrm{ml}^{-1}$ After $30 \mathrm{~min}$, flow of $15^{\circ} \mathrm{C}$ well water was resumed to the aquaria. The 2 additional tanks served as uninfected controls and fish in these groups were treated in a similar manner but exposed only to MEM. Mortalities were recorded in one experimental and one control group. Fish in the replicate experimental group were examined for presence of the virus by removal of 4 fish at Weeks 1 and 2, and examination of mortalities occurring on other days. Four fish from the replicate control group were examined at Weeks $1,2,4,6$ and at $50 \mathrm{~d}$ when the experiment was terminated. 

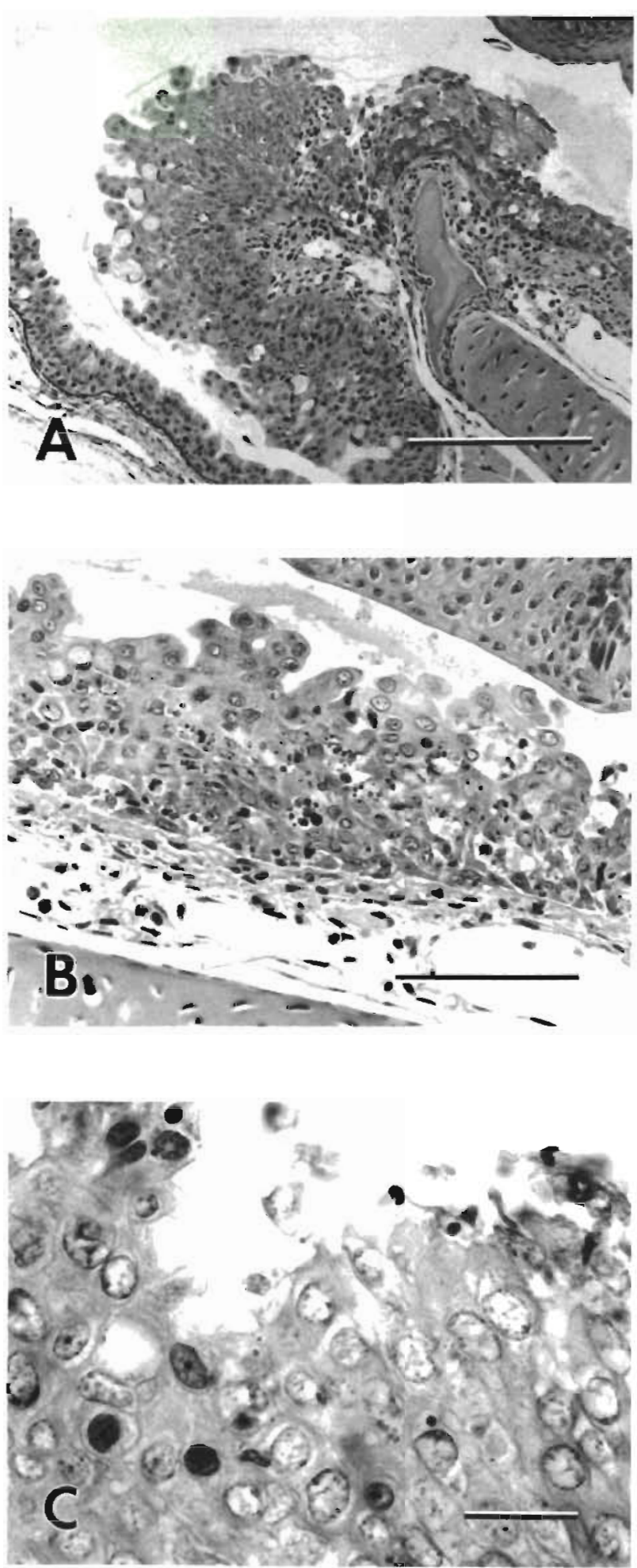

Fig. 1. Acipenser transmontanus. Hematoxylin-stained tissue sections of the epidermis of juvenile fish infected with white sturgeon herpesvirus (WSHV). (A) Hyperplastic focus of the oral mucocutaneous junction. Bar $=200 \mu \mathrm{m}$. (B) Swollen cells on the surface and necrosis of deeper layers. Bar $=100 \mu \mathrm{m}$. (C) Hypochromatic enlarged nuclei with margination of chromatin. Bar $=20 \mu \mathrm{m}$

\section{RESULTS}

\section{Gross signs}

There were no specific external signs associated with natural infections among juvenile white sturgeon. Internally, the fish had fluid-filled stomachs and intestines but otherwise appeared normal. Mortalities up to $50 \%$ occurred among certain groups of farm-reared fish from which the virus was recovered.

\section{Light microscopy}

Microscopic examinations of hematoxylin and eosin stained tissue sections revealed a focal to focally diffuse dermatitis (Fig. 1A). Distribution of lesions was variable among fish although all had involvement of the oral mucocutaneous junction (Fig. 1A). The lesions were characterized by acanthosis and intercellular edema. Intraepidermal spaces that were clear or contained cellular debris were common (Fig. 1B). There was hydropic degeneration and hypertrophy of the malphigian cells with a loss of intercellular junctions. Swollen cells had a fine granular to fibrillar eosinophilic to amphophilic cytoplasm and slightly enlarged hypochromatic nuclei with margination of the nuclear chromatin (Fig. 1C). Chromatin margination was occasionally associated with the presence of flocculent, non-membrane-bound intranuclear inclusions. Mitotic figures were common. There was sloughing of individual necrotic cells with the subsequent formation of erosive foci in the integument. Although occasionally

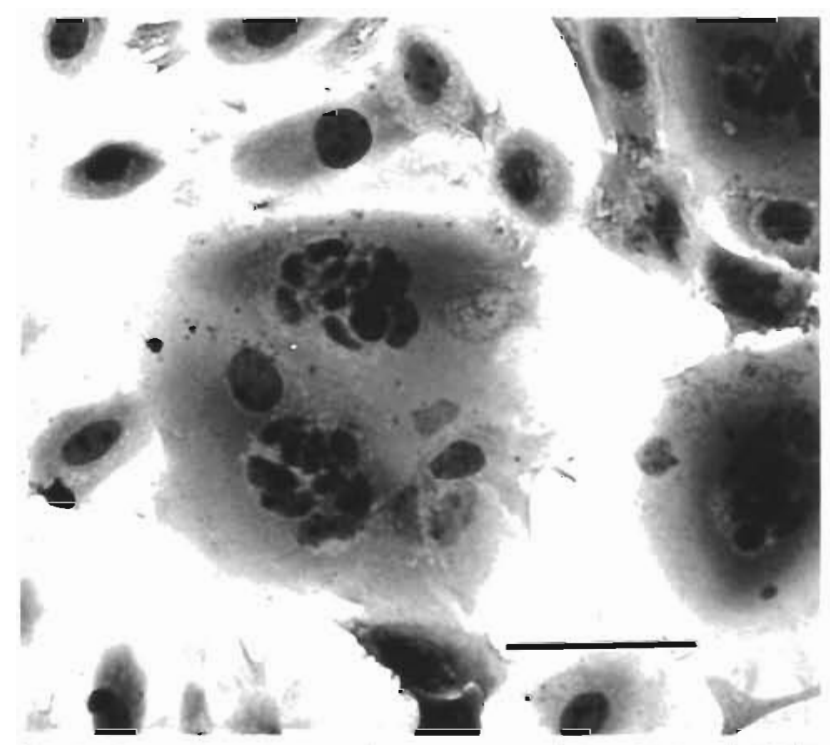

Fig. 2. Syncytium in the white sturgeon skin cell line (WSSK1) $48 \mathrm{~h}$ following infection with WSHV at $15^{\circ} \mathrm{C}$. Giemsa stain. $\mathrm{Bar}=25 \mu \mathrm{m}$ 
observed, ulceration was not a common finding even though the entire epidermis to the basal lamina was affected Inflammation was limited to a mild infiltration of mononuclear cells within the dermis. There were no indıcations of involvement of other tissues. Mild hyperplasia of the gill epithelium was observed in several fush but there was no indication of involvement of the respiratory epithelium.

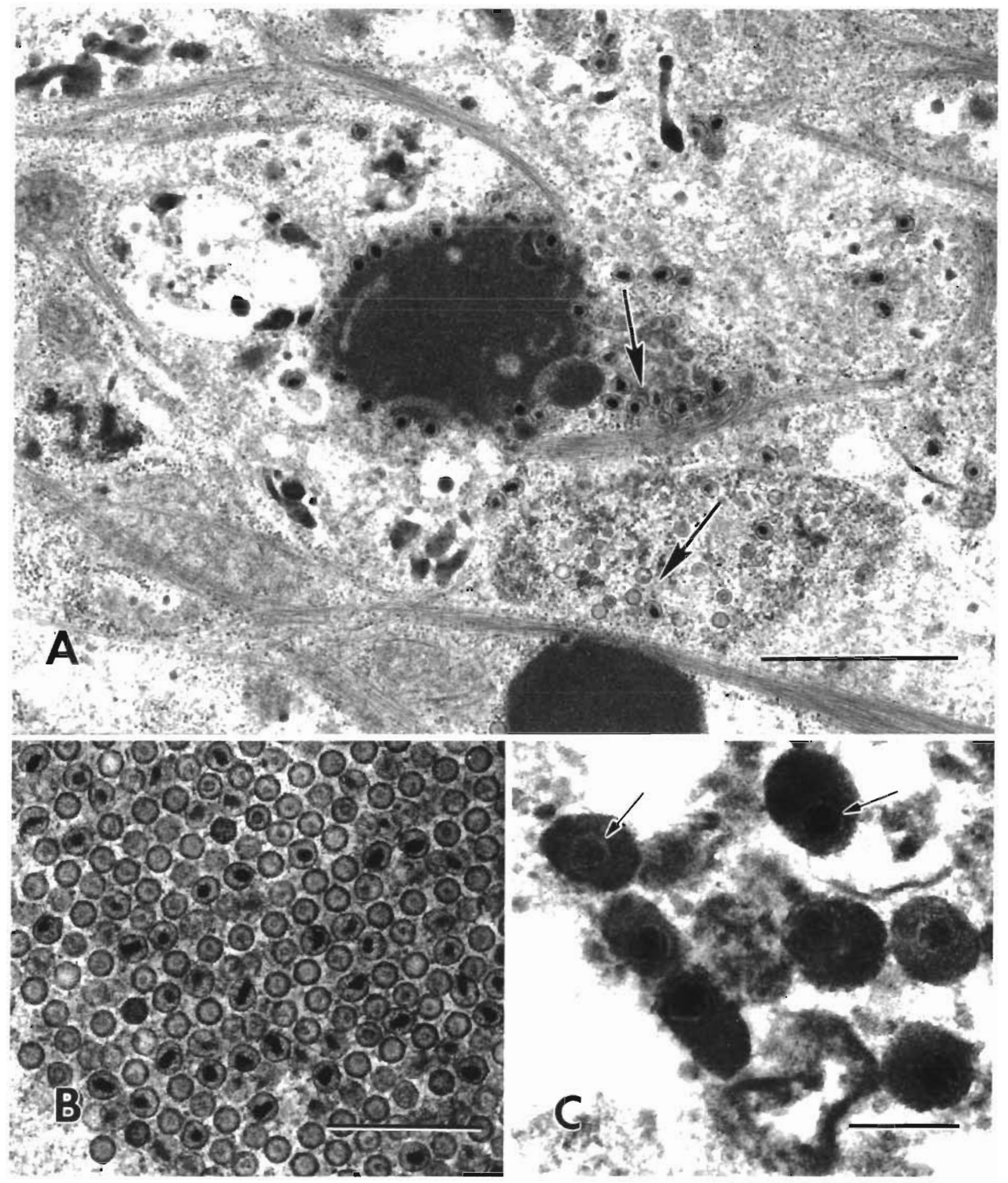

Fig. 3. Electron micrographs of WSHV from infected WSSK-1 cells. (A) Formation of nucleocapsids (arrows) associated with a fibrillar material in the cytoplasm. Bar $=1 \mathrm{um}$. (B) An accumulation of nucleocapsids in the nucleus. Bar $=500 \mathrm{~nm}$. (C) Virions (arrows) surrounded by envelopes within cytoplasmic vacuoles. Bar $=100 \mathrm{~mm}$ 


\section{Virus isolation}

Syncytia were detected in WSSK-1 cells 3 d after incubation with extracts from affected white sturgeon (Fig. 2). After 5 d of incubation, the entire cell sheet became involved and the cells had all detached from the bottom of the flask by $7 \mathrm{~d}$ post-inoculation. There was no evidence for cytopathic effects (CPE) in the WSH-1 or WSS-2 line or in CHSE-214 or EPC cells. Subcultures of the virus onto WSSK-1 cells induced CPE after $2 \mathrm{~d}$ at $15^{\circ} \mathrm{C}$. A second examination of the same group of fish $3 \mathrm{wk}$ later also resulted in isolation of the virus. The virus was routinely isolated from moribund fish from the population moved to the laboratory for a period up to $5 \mathrm{wk}$ and cumulative mortality reached $97 \%$. However, infections with Flexibacter columnaris that developed after movement of fish to the laboratory were prevalent and assumed to be a contributing factor to the observed mortality.

\section{Electron microscopy}

Virions were found in both the nucleus and cytoplasm of cells directly from infected fish and infected WSSK-1 cells (Fig. 3). Nucleocapsids were found in the cytoplasm associated with fibrillar structures and a fine granular electron dense material (Fig. 3A). Numerous nucleocapsids $(110 \mathrm{~nm}$ in diameter) were found within the nucleus. These nucleocapsids often contained an electron-dense center (Fig. 3B). Enveloped particles were observed within cytoplasmic vacuoles. These mature particles had an electron-dense core and a hexagonal nucleocapsid and were surrounded by a coarse electron-dense tegument with a limiting external envelope $230 \mathrm{~nm}$ in diameter (Fig. 3C).

\section{Growth temperatures}

WSHV grew at 10,15 , and $20^{\circ} \mathrm{C}$ but not at 5 or $25^{\circ} \mathrm{C}$ (Fig. 4). Virus replication occurred most rapidly at 15

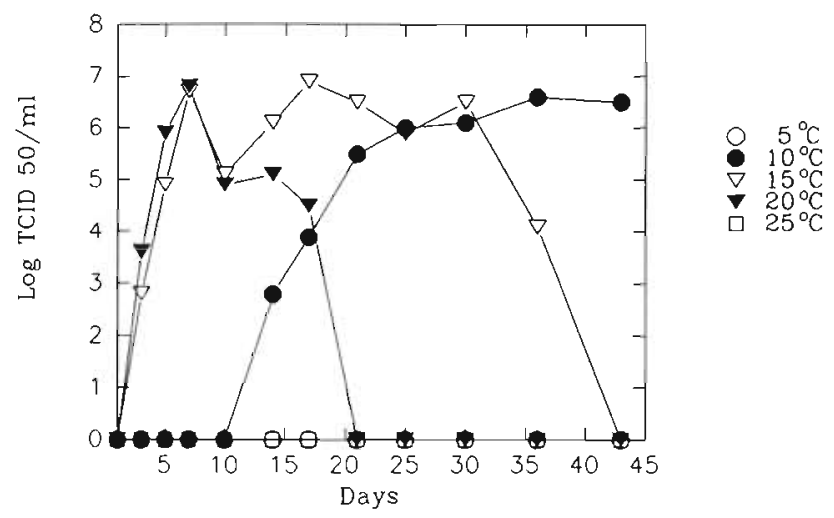

Fig. 4. Growth of the WSHV in WSSK-1 cells at 5 temperatures and $20^{\circ} \mathrm{C}$, reaching peak concentrations by $7 \mathrm{~d}$ postinfection. However, this was followed by a quick decline in titer after $17 \mathrm{~d}$ at $20^{\circ} \mathrm{C}$. The growth rate of the virus at $15^{\circ} \mathrm{C}$ was equal to that observed at $20^{\circ} \mathrm{C}$ but, in contrast to the higher temperature, concentrations up to $10^{65} \mathrm{TClD}_{50} \mathrm{ml}^{-1}$ were still present at $30 \mathrm{~d}$ after infection of WSSK-1 at $15^{\circ} \mathrm{C}$ (Fig. 4). Virus growth was slower at $10^{\circ} \mathrm{C}$ compared to 15 and $20^{\circ} \mathrm{C}$ but the maximum concentrations of the virus reached were equivalent at all 3 temperatures.

\section{Infection trial}

A cumulative mortality of $35 \%$ occurred among juvenile sturgeon exposed to $10^{5.3} \mathrm{TCID}_{50} \mathrm{ml}^{-1}$ of virus (Fig. 5). The virus was recovered from $3 / 7$ fish that died during the study. There were no mortalities among the control group. Examinations of live fish from the parallel exposed group showed $2 / 4$ and $1 / 4$ fish at 1 and 2 wk post-infection to be infected. Virus was not recovered from fish examined at 4 and $6 \mathrm{wk}$ or $50 \mathrm{~d}$ post-infection or among control fish examined at any time.

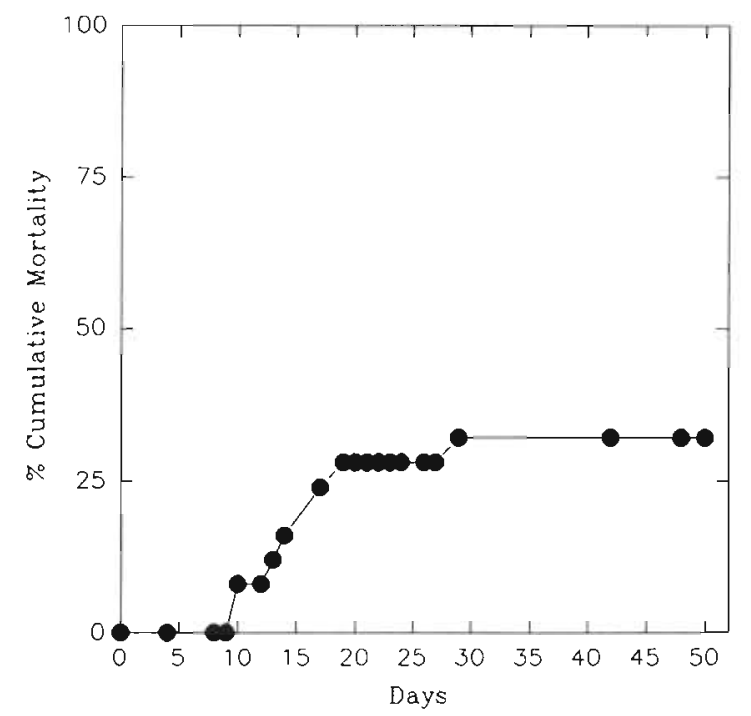

Fig. 5. Acipenser transmontanus. Mortality among juvenile white sturgeon following waterborne exposures to $10^{5.3}$ $\mathrm{TCID}_{50} \mathrm{ml}^{-1}$ of WSHV at $15^{\circ} \mathrm{C}$. There were no mortalities among a control group treated in the same manner but not exposed to the virus

\section{DISCUSSION}

The herpesvirus described in this study is the third known viral pathogen detected among juvenile white sturgeon reared in captivity. All 3 viruses have been detected among populations of juvenile white sturgeon undergoing increased mortality. The herpesvirus 
described in this paper, and the iridovirus (WSIV), have now been isolated and shown to induce mortality in experimental infections (unpubl.). The WSIV appears to be the more common and pathogenic of the 2 agents as shown by the severity of both natural and experimental infections and its annual recurrence among juvenile white sturgeon reared in several farms (Hedrick et al. 1990, unpubl.). The characteristics of the adenovirus, or WSAV, are the most poorly understood of the 3 sturgeon viruses largely due to the inability to isolate the virus and its apparent absence among farmreared white sturgeon since 1986.

Gross external signs were not detected among naturally-occurring or experimentally induced infections with the herpesvirus (WSHV). This contrasts with infections with both WSIV and WSAV which are often associated with a 'wasting syndrome' in which juvenile fish cease eating, congregate at the bottom of the tank, and become progressively emaciated (Hedrick et al. 1990). In contrast to WSIV infections, mortalities among farm-reared sturgeon with WSHV occurred in the more rapidly growing and most healthy appearing fish. The inability to detect any other pathogens or adverse environmental factors, combined with the serious nature of the skin lesions in fish at the farm, lead us to conclude that WSHV alone can induce mortality. This view is supported by the results of experimental infections of juvenile sturgeon in which mortality followed waterborne exposures to the virus. The apparently low rate of recovery of virus from mortalities (3/7) may be due in part to the length of time between mortality and virus examinations, since several fish died during the night and were not collected until the next day. We have experienced similar difficulties in recovering the channel catfish herpesvirus (CCV) (Fijan et al. 1970) from experimentally-infected catfish if the time between death and collection is several hours (unpubl.).

The syncytia induced by WSHV is typical of the CPE observed with other fish herpesviruses (Fig. 2). There was no evidence for the same type of intranuclear inclusion bodies seen in epidermal cells of infected fish in our stained cell preparations of virus-infected WSSK-1 cells. The rapid growth and high concentrations of virus produced by WSHV infections in WSSK-1 cells however, contrasts to the slower rates and less productive infections of most herpesviruses isolated from fish (Wolf 1988, Hedrick \& Sano 1989). This may in part be due to the compatibility between the virus and the target cell (an epidermally derived line) as shown by the preference of WSHV for the WSSK-1 line and the failure of virus to grow in other lines derived from white sturgeon (WSS-2 and WSH-1), salmonids or cyprinids. The tropism of the virus for cells of epidermal origin was clearly revealed by microscopic examinations of tissues from infected fish (Fig. 1).
The WSHV was recovered from fish examined directly from the farm on 2 occasions and repeatedly from the same population of fish after transfer to our laboratory The virus was no longer detected after $5 \mathrm{wk}$ from the first isolation. Viral-induced CPE was evident within $3 \mathrm{~d}$ after cells were inoculated with homogenates from infected fish. This incubation period is relatively short in comparison to the 14 to $21 \mathrm{~d}$ often required for isolation of the WSIV. The sturgeon herpesvirus growth was even more rapid in subcultures where CPE was easily observed after $2 d$ post-inoculation. Virus replication occurred at temperatures between 10 and $20^{\circ} \mathrm{C}$ (Fig. 4), which correspond to water temperatures commonly encountered in farms rearing sturgeon in California. Even though substantial concentrations of WSHV are produced from WSSK-1 cells at $20^{\circ} \mathrm{C}$, the stability of infectious virions is apparently poor as shown by the rapid decline in titers beginning at $17 \mathrm{~d}$ (Fig. 4).

The rapid replication and virus concentrations approaching $10^{7} \mathrm{TCID}_{50} \mathrm{ml}^{-1}$ reached by WSHV in the WSSK-1 line are comparable to those obtained with 2 other herpesviruses, CCV in the channel catfish ovary (CCO) line (Wolf \& Darlington 1971, Bowser \& Plumb 1980) and the salmonid nerka virus (NeVTA) in CHSE214 cells (Sano 1976). However, both CCV and NeVTA belong to the minor group of fish herpesviruses which cause systemic infections (Fijan et al. 1970, Sano 1976), being less specific for the cell types infected in vivo and in vitro. A recently identified herpesvirus from Japanese eels Anguilla japonica apparently can also induce a systemic disease (Sano et al. 1990a). In contrast, most herpesviruses detected in fish are associated with nonfatal hyperplastic, or in one case a neoplastic, conditions of the epidermis (Wolf 1988, Hedrick \& Sano 1989). However, the pathogenicity and ability to cause systemic disease in young fish has been demonstrated for certain viruses isolated from epidermal growths. Kimura et al. (1981a, b) and Sano et al. (1983) demonstrated the pathogenic nature of certain salmonid herpesvirus type 2 strains for young salmonids. Sano (1988) and Sano et al. (1990b) also found similar systemic infections in young carp following experimental infections with Herpesvirus cyprini, a virus isolated from hyperplastic skin growths of adult carp. The studies with type 2 salmonid herpesviruses and $H$. cyprini have shown that herpesviruses isolated from even somewhat benign growths (e.g. as with $H$. cyprini) may be pathogenic to young immunologically naive fish. Models for recurrent infections following an acute initial infection are characteristic of herpesviruses from mammals (Kirchner 1982). In fish, these later periods of viral replication may be manifested by induction of dermatic lesions including papillomatous, neoplastic or ulcerative conditions (Kimura et al. 1981a, 
b, Leibovitz \& Lebouitz 1985, Sano et al, 1985a, b, Sano et al 1990b). These observations with other herpesviruses may indicate that WSHV can induce more serious systemic infections in very young fish (e.g. larvae) than the more localized infections of the integument we observed in 1 to $3 \mathrm{~g}$ fish.

The infections of the integument with WSHV resemble descriptions of 2 additional herpesviruses shown to be the cause of naturally occurring diseases among juveniles or larvae. Epizootic epitheliotropic disease virus (EEDV) of lake trout Salvelinus namaycush and the Japanese flounder Paralichthys olivaceus herpesvirus have both been implicated in natural and experimental studies as the cause of serious epidermal infections resulting in up to $100 \%$ mortalities among infected fish (Bradley et al. 1989, lida et al. 1989). The infections described from lake trout share several features with those induced by WSHV. These include an initial hyperplasia followed by necrosis and sloughing of the epidermis in the absence of a marked host inflammatory response. The similarity of these microscopic lesions of the epidermis, especially the oral mucocutaneous junction with both EEDV- (Bradley et al. 1989) and WSHV-infected fish (Fig. 1), is remarkable. Unfortunately, further comparison of WSHV to EEDV and the flounder herpesvirus will be difficult since the latter 2 agents have yet to be isolated in cell cultures or cell lines. Since most fish herpesviruses show fairly narrow host ranges, we presume that all 3 agents (WSHV, EEDV and the flounder herpesvirus) are unique viruses. This presumption is in part confirmed by the lack of infection among juvenile lake trout following experimental exposures to WSHV in our laboratory (unpubl.).

Further studies on the pathogenicity of WSHV to larval sturgeon and the possible relationship of the virus to a recurrent skin disease in older specimens are underway. A primary etiology has not been found for the latter condition which is associated with low grade mortalities among more valuable market size fish. The biochemical and serological relatedness of WSHV to other herpesviruses isolated from fish is also under investigation to determine the diversity that may exist between viruses isolated from rather primitive fishes (sturgeon) compared to those from more highly evolved teleost species such as cyprinid fishes.

Acknowledgements. This work was supported in part by Dingell-Johnson/Wallop-Breaux Fish Restoration Act funds administered through the California Department of Fish and Game. We thank Mr J. Michaels for his assistance and ideas, the technicians of the Veterinary Medicine Teaching Hospital for their preparations of stained tissue sections for light microscopy, and Dr S. Chilmonczyk and Mr R. Munn for their electron microscopy expertise.

\section{LITERATURE CITED}

Amos, K. (1985). Procedures for the detection of certain fish pathogens. Fish Health Section Bluebook, American Fisheries Society, Bethesda, Maryland

Bowser, P. R., Plumb, J. A. (1980). Fish cell lines: establishment of a line from ovaries of channel catfish. In Vitro 16 365-368

Bradley, T., Chang, P., Medina, D., McClain, J. (1989). Epizootic epitheliotropic disease of lake trout (Salvelinus namaycush): history and viral etiology. Dis. aquat. Org. 7 195-201

Fijan, N., Sulimanovic, D., Bearzotti, M., Muzinine, D., Zwillenberg, L. D., Chilmonczyk, S., Vantheron, S. F., de Kinkelin, P. (1983). Some properties of the Epithelioma papillosum cyprini (EPC) line from common carp Cyprinus carpio. Ann. Virol. 134:207-220

Fijan, N. N., Wellborne, T. L. Jr, Naftel, J. P. (1970). An acute viral disease of channel catfish. U.S. Sport Fisheries and Wildlife Technical Paper No. 43,11 p.

Hedrick, R. P., Groff, J. M., McDowell, T S., Wingfield, W. H. (1990). An iridovirus from the integument of white sturgeon. Dis. aquat. Org. 8: 39-44

Hedrick, R. P., McDowell, T. S., Rosemark, R., Aronstein, D. Lannan, C. N. (1991). Two cell lines from white sturgeon. Trans. Am. Fish. Soc. (in press)

Hedrick, R. P., Sano, T (1989). Herpesviruses of fishes. In: Ahne, W., Kurstak, E. (eds.) Viruses of lower vertebrates. Springer-Verlag, Munich, 161-170 p

Hedrick, R. P., Speas, J., Kent, M. L., McDowell, T (1985). Adeno-like virus associated with a disease of cultured white sturgeon (Acipenser transmontanus). Can. J. Fish. Aquat. Sci. 42: 1321-1325

Humason, G. L. (1979). Animal tissue techniques. W. H. Freeman Co., San Francisco

Iida, Y., Masumura, K., Nakai, T., Sorimachi, M., Matsuda, H. (1989). A viral disease occurred in larvae and juveniles of Japanese flounder, Paralichthys olivaceus. J. aquat. Anim. Health 1: 7-12

Kimura, T., Yoshimizu, M., Tanaka, M. (1981a). Studies on a new virus (OMV) from Oncorhynchus masou - II. Characteristics and oncogenicity. Fish Pathol. 15: 149-153

Kimura, T., Yoshimizu, M., Tanaka, M., Sannohe, H. (1981b). Studies on a new virus (OMV) from Oncorhynchus masou - 1. Characteristics and pathogenicity. Fish Pathol. 15: 143-147

Kirchner, H. (1982). Immunobiology of infection with herpes simplex virus. Monogr. Virol. 13: 10-12

Lannan, C. N., Winton, J. R., Fryer, J. L. (1984). Fish cell lines: establishment and characterization of nine cell lines from salmonids. In Vitro 20: 671-676

Leibovitz, L., Lebouitz, S. S. (1985). A viral dermatitis of the smooth dogfish, Mustelus canis (Mitchill). J. Fish Dis. 8: $273-279$

Reed, L. J., Muench, H. (1938). A simple method of estimating fifty percent endpoints. Am. J. Hygiene 27: 493-497

Sano, T. (1976). Viral diseases of cultured fishes in Japan. Fish Pathol 10: 221-226

Sano, T (1988). Characterization, pathogenicity and oncogenicity of herpesviruses in fish. Abstract from the American Fisheries Society, Fish Health Section International Fish Health Conference, Vancouver, British Columbia, Canada. July 19-21. p. 157

Sano, T., Fukuda, H., Furukawa, M. (1985b). Herpesvirus cyprini: biological and oncogenic properties. Fish Pathol. 20: $381-388$

Sano, T., Fukuda, H., Furukawa, M., Hosoya, H., Moriya, Y. 
(1985a). A herpesvirus isolated from carp papilloma in Japan. In: Ellis, A. E. (ed.) Fish and shellfish pathology. Academic Press, London, p. 307-311

Sano, T., Fukuda, H., Okamoto, N., Kaneko, F. (1983). Yamame tumor virus: lethality and oncogenicity. Bull. Jap. Soc. scient. Fish. 49: 1159-1163

Sano, M., Fukuda, H., Sano, T. (1990a). Isolation and characterization of a new herpesvirus from eel. In: Perkins, F. O.,

Responsible Subject Editor: W. Ahne, Munich, Germany
Cheng, T C. (eds.) Pathology in marine science. Academic Press, New York, p. 15-31

Sano, T., Morita, N., Shima, N., Akimoto, M. (1990b). A preliminary report on pathogenicity and oncogenicity of cyprinid herpesvirus. Bull. Eur. Ass. Fish Pathol. 10: 11-13

Wolf, K. (1988). Fish viruses and viral diseases. Cornell University Press, Ithaca, New York

Wolf, K., Darlington, R. W. (1971). Channel catfish virus: a new herpesvirus of ictalurid fish. J. Virol. 8: 525-533

Manuscript first received: December 12, 1990

Revised version accepted: March 6, 1991 